\title{
VENIA LEGENDI Z ZAKRESU FILOLOGII NA UNIWERSYTECIE JAGIELLOŃSKIM OD DRUGIEJ POŁOWY XIX WIEKU DO 1939 ROKU ORAZ DALSZE LOSY WYHABILITOWANYCH DOCENTÓW
}

\author{
Przemysław Marcin Żukowski \\ Uniwersytet Jagielloński w Krakowie
}

\begin{abstract}
VENIA LEGENDI IN THE FIELD OF PHILOLOGY AT THE JAGIELLONIAN UNIVERSITY FROM THE SECOND HALF OF THE NINETEENTH CENTURY TO 1939 AND FURTHER FATE OF HABILITATED DOCENTS

This paper gives an overview of 71 persons who tried to obtain the right to give lectures on philology at the Faculty of Philosophy at the Jagiellonian Universityin the years 1862-1939. Out of them, 60 persons received the venia legendi, but 11 were denied that right. While the article takes into account a small group of scholars, some conclusions and generalizations can be made, such as, for example, that it is certain that philology schools were founded in Cracow. Thus, it is easier to capture the master-student relationship. Most of the privat-docents (docents), after obtaining the venia legendi, still remained "in school" and received university chairs not only at the Jagiellonian University but also at other universities. A Cracow's docent, who could not count on a chair at the Jagiellonian University - not because of inadequate qualifications but because of budgetary reasons - received a professor's chair at one of the other universities of the Second Polish Republic (not counting Lwow): in Vilnius, Warsaw or Poznań.

Key words: Jagiellonian University, Cracow, history of science, habilitation, docents, Faculty of Philosophy, Polish philology, classical philology, Roman philology, German philology, English philology, Oriental philology, Russian philology, Indo-European linguistics.

Słowa kluczowe: Uniwersytet Jagielloński, historia nauki, habilitacja, docenci, Wydział Filozoficzny, filologia polska, filologia klasyczna, filologia romańska, filologia niemiecka, filologia angielska, filologia orientalna, filologia ruska, językoznawstwo indoeuropejskie. 
Jako normalny system powołania sił naukowych wprowadzony zostaje system habilitacji (i uczenia przez pewien czas w charakterze ,docenta”) przedtem niepraktykowany, a wydaje on jak najlepsze rezultaty. Tym to okolicznościom zawdzięcza w dużej mierze Kraków, że ówczesne pokolenie profesorów - elita z całej Polski - staje na tej wyżynie, jakiej nie widziano w Krakowie od wieku XV. Pokolenie to obfituje w pierwszorzędne talenty organizacyjne i naukowe, a charakterystyczną jego cechą jest humanizm w duchu: nihil humani a me alienum esse puto ${ }^{1}$.

Tak o wprowadzeniu tytułu docenta prywatnego w drugiej połowie XIX wieku oraz związania osób prawem wykładania danej dziedziny naukowej z Uniwersytetem Jagiellońskim napisał przed laty Stanisław Estreicher. Krzysztofa Michalewska wskazała dodatkowo w swoim artykule dotyczącym habilitacji na UJ, że z jednej strony ,[...] powołanie do życia takiej instytucji” przypadło na wspomnianej uczelni stosunkowo późno w porównaniu z innymi uniwersytetami monarchii austriackiej, ale za to ,[...] zawdzięczał [temu - P.M.Ż.] Uniwersytet, po roku 1870, swój nowoczesny charakter i rozwój naukowy" . Warto z kronikarskiego obowiązku dodać, że ten swoisty „,boom” wniosków o udzielenie venia legendi i przyznania tytułu docenta prywatnego rozpoczął się w 1862 roku, po zamieszczeniu w krakowskim „Czasie” artykułu Józefa Dietla $O$ instytucji docentów w ogóle, a szczególnie w Uniwersytecie Jagiellońskim³.

Instytucja docentów prywatnych (a co za tym idzie - procedura habilitacji) rozwinęła się najbardziej w krajach niemieckojęzycznych, a najwcześniej, bo na początku XIX wieku, na uniwersytetach niemieckich ${ }^{4}$. W monarchii austriackiej zaadaptowano i te niemieckie rozwiązania. Na UJ pierwsze zatwierdzone przez rząd w Wiedniu habilitacje odbyły się w 1862 roku. Na Wydziale Prawa pierwszy był Fryderyk Zoll senior, który 9 kwietnia 1862 roku uzyskał jej zatwierdzenie przez Ministerstwo Wyznań i Oświaty z zakresu prawa rzymskiego ${ }^{5}$. Na Wydziale Filozoficznym byli to Jan Kowalczyk oraz Władysław Zajączkowski. Otrzymali oni zatwierdzenie 23 kwietnia 1862 roku $^{6}$.

W omawianym okresie - od drugiej połowy XIX wieku do 1939 roku - procedurę uzyskania venia docendi - bo tak według ówczesnych przepisów brzmiała nazwa - regulowało rozporządzenie MWiO z 11 lutego 1888 roku, które w większości swoich postanowień utrzymało w mocy rozwiązania rozporządzenia z 19 grudnia

1 S. Estreicher, Znaczenie Krakowa dla życia narodowego polskiego w ciagu XIX wieku, Kraków 1931, s. 34.

2 K. Michalewska, Habilitacje w Uniwersytecie Jagiellońskim 1848-1918, „Zeszyty Naukowe Uniwersytetu Jagiellońskiego” 1963, nr 71, „Prace Historyczne”, z. 12, s. 1.

3 „Czas”, nr 251 z 31 X 1861 r.

4 E. Horn, Zur Gesichte der Privatdozenten [w:] Mitteilungen der Gesellschaft für deutsche Erziehungs- und Schulgeschichte, Vol. 11, Berlin 1901.

5 Archiwum Uniwersytetu Jagiellońskiego w Krakowie (dalej: AUJ), S II 619, Teczka personalna F. Zolla sen.; WP II 138, Teczka personalna F. Zolla sen. Zob. szerzej: P.M. Żukowski, Profesorowie Wydziału Prawa Uniwersytetu Jagiellońskiego, t. 2: 1780-2012, red. D. Malec, Kraków 2014, s. 599 i nn.; K. Michalewska, op. cit., s. 73 i nn.; M. Patkaniowski, Dzieje Wydziatu Prawa Uniwersytetu Jagiellońskiego od reformy kołtątajowskiej do końca XIX stulecia, Kraków 1964, s. 318 i nn.

${ }^{6}$ U. Perkowska, Corpus Academicorum Facultatis Philosophiae Universitatis Iagellonicae 1850 1945, Kraków 2007. 
$1848 \mathrm{roku}^{7}$. Przepisy te, ukształtowane w XIX wieku, przetrwały niemal niezmienione do lat 30. XX wieku, a jedną z niewielu modyfikacji było wprowadzenie przez polskie ustawodawstwo terminu venia legendi. Aby nie czynić niepotrzebnego zamieszania pojęciowego (oba terminy oznaczają to samo), w pracy będę używać tego drugiego określenia. O instytucji docentów i ich habilitowaniu wspominały - obowiązujące w czasie istnienia II Rzeczypospolitej - dwie ustawy o szkołach akademickich: z 13 lipca $1920 \mathrm{roku}^{8}$ oraz z 15 marca 1933 roku $^{9}$ (tzw. jędrzejewiczowska). Nadal pozostało w mocy rozporządzenie austriackie z 11 lutego 1888 roku o habilitacjach. Po uchwaleniu 10 marca 1925 roku przez Senat Akademicki UJ i zatwierdzeniu 25 maja 1925 roku przez ministra wyznań religijnych i oświecenia publicznego Stanisława Grabskiego pewne szczegóły habilitacji doprecyzował Statut UJ. Przepisy weszły w życie 1 lipca 1925 roku, a kwestie habilitacji omawiały paragrafy 52-67. Polskie rozporządzenie o sposobie przeprowadzenia postępowania habilitacyjnego w państwowych szkołach akademickich zostało wprowadzone 21 kwietnia 1936 roku $^{10}$, a zmienione rozporządzeniem z 26 lipca 1939 roku (dodano paragraf 13a) ${ }^{11}$. Przepisy o habilitacjach, z kosmetyczną nowelizacją z 25 czerwca 1945 roku $^{12}$, obowiązywały, z czego mało kto zdaje sobie sprawę, jeszcze w latach 40 . XX wieku, po zakończeniu II wojny światowej, aż do likwidacji tytułu docenta wraz z wprowadzeniem radzieckich rozwiązań w polskiej nauce. Warto tutaj zacytować akt prawny - ustawę z 13 lipca 1920 roku. Czytamy w nim:

Rada Wydziałowa może udzielić ubiegającemu się o to kandydatowi prawo wykładania (venia legendi); postępowanie prowadzące do tego celu nazywa się habilitacją, kandydat zaś, któremu zostało przyznane prawo wykładania w szkole akademickiej, otrzymuje tytuł docenta.

Prawo wykładania obejmować ma całość pewnej nauki lub takiej jej części, która może być uważana za całość w sobie zamkniętą; nie może natomiast ograniczać się do dowolnego działu pewnej nauki ${ }^{13}$.

Oznacza to, że nieuprawnione jest przenoszenie dzisiejszego postępowania habilitacyjnego, zmierzającego do nadania stopnia naukowego doktora habilitowanego, na ówczesne rozwiązania. Ustawodawca wyraźnie zaznaczył, że proces prowadzący

7 Die österreichischen Universitätsgesetze. Sammlung der für die österreichischen Universitäten gültigen Gesetze, Verordnungen, Erlässe, Studien- und Prüfungsordnungen, Hrsg. L. Beck von Mannagetta, C. von Kelle, Wien 1906, s. 169. Zob. szerzej: AUJ, WP II 137, Habilitacje i docentury, reskrypt $\mathrm{MWiO}$ z 11 II $1888 \mathrm{r}$.

8 Ustawa z 13 VII 1920 r. o szkołach akademickich, DzURP 1920, nr 72, poz. 494.

9 Ustawa z 15 III 1933 r. o szkołach akademickich, DzURP 1933, nr 29, poz. 247.

10 Rozporządzenie Ministra WRiOP z 21 IV 1936 r. o sposobie postępowania habilitacyjnego w państwowych szkołach akademickich, DzURP 1936, nr 38, poz. 290.

11 Rozporządzenie Ministra WRiOP z 26 VII 1939 r. o sposobie postępowania habilitacyjnego w państwowych szkołach akademickich, DzURP 1939, nr 69, poz. 468. Zob. szerzej: J. Jastrzębski, Habilitacja w państwowym szkolnictwie akademickim II Rzeczypospolitej, „Analecta. Studia i Materiały z Dziejów Nauki” R. XIX, 2010, z. 1-2, s. 63 i nn.; Zbiór przepisów o szkolnictwie akademickim. Ustawy, rozporzadzenia, okólniki, zebr. A. Ostrow ski, Lwów-Warszawa 1938, passim.

12 Rozporządzenie Ministra Oświaty z 25 VI 1945 r. w sprawie postępowania habilitacyjnego w państwowych szkołach akademickich, DzURP 1945, nr 24, poz. 139.

13 Ustawa z 13 VII 1920 r. o szkołach akademickich, DzURP 1920, nr 72, poz. 494, art. 50. 
do nadania prawa wykładania nazywany jest habilitacją, a nie na przykład przewodem habilitacyjnym. Również wprost stwierdzono, iż osoba uzyskiwała w wyniku tego procesu tytuł docenta, a nie stopień naukowy. Dodam na marginesie, że w czasach austriackich był jeden stopień naukowy - doktor, a w II Rzeczypospolitej dwa stopnie naukowe: niższy ${ }^{14} \mathrm{i}$ wyższy (stopień doktora). Wszystkich zainteresowanych przebiegiem procedury zmierzającej do uzyskania prawa wykładania odsyłam do literatury naukowej ${ }^{15}$.

Od 1862 do 1939 roku na fakultecie filozoficznym UJ venia legendi uzyskało 60 naukowców, a 11 osobom odmówiono nadania prawa prowadzenia wykładów. Wniesionych podań było jednak znacznie więcej, gdyż kilka osób rozszerzyło posiadaną już habilitację, zdarzało się również, że jedna osoba składała podanie kilkukrotnie (zob. tab. 1, 2). Zdecydowana większość charakteryzowała się wysokim poziomem naukowym i nie miała problemów ani z przeprowadzeniem habilitacji, ani z formalnym uzyskaniem zatwierdzenia ministerialnego. Niemniej zdarzały się wyjątki... Niekiedy przedkładano jako rozprawy prace „popularyzacyjne” niespełniające wymagań stawianych rozprawom naukowym. Złożone wnioski - ze względu na przebieg procedury - możemy pogrupować następująco:

- habilitacje przeprowadzone bez problemu i według „,klasycznej” procedury;

- habilitacje, które przeszły bez zastrzeżeń, ale Rada Wydziału zwolniła habilitowanych z drugiego lub/i trzeciego stadium habilitacji;

- habilitacje rozszerzone;

- habilitacje przeniesione z innej uczelni;

- habilitacje, które zakończyły się niepowodzeniem na szczeblu wydziałowym.

Tabele 1 i 2 zawierają zbiorcze zestawienie złożonych podań.

Tabela 1. Habilitacje zatwierdzone

\begin{tabular}{|l|c|l|}
\hline \multicolumn{1}{|c|}{ Przedmiot (zakres) } & Liczba & \multicolumn{1}{c|}{ Osoba } \\
\hline Filologia niemiecka & 4 & $\begin{array}{l}\text { H. Anders } \\
\text { A. Kleczkowski } \\
\text { Z. Lempicki } \\
\text { K. Petelenz (język niemiecki, historia literatury } \\
\text { niemieckiej) }\end{array}$ \\
\hline
\end{tabular}

14 Tutaj chciałbym wytłumaczyć, że ustawodawca świadomie nie wymienił wprowadzonego polskimi rozporządzeniami wykonawczymi stopnia magistra, gdyż - jeżeliby tak uczynił - pozbawiłby prawa ubiegania się o stopień doktora wszystkich absolwentów uniwersytetów austriackich, niemieckich i rosyjskich (z zastrzeżeniem istniejącego tam stopnia kandydata), gdzie takowego stopnia nie było, a studia kończyły się uzyskaniem absolutorium.

15 AUJ, S II 583, Docenci prywatni; AUJ, WP II 137, Habilitacje i docentury. Zob. szerzej: M. Przeniosło, Stopnie, tytuly i stanowiska naukowe w II Rzeczypospolitej, „Res Historica” 2012, s. 160 i nn.; Statut UJ, s. 20 i nn.; K. Wojtczak, O stopniach naukowych $i$ veniam legendi $w$ II Rzeczypospolitej (część I), „Studia Prawa Publicznego” 2014, nr 3, s. 31 i nn.; idem, O stopniach naukowych i veniam legendi w II Rzeczypospolitej (część II), „Studia Prawa Publicznego” 2014, nr 4 (8), s. 11 i nn. 


\begin{tabular}{|c|c|c|}
\hline Historia literatury polskiej & 16 & $\begin{array}{l}\text { A. Bełcikowski } \\
\text { J. Birkenmajer } \\
\text { H. Gaertner (filologia polska, historia starszej } \\
\quad \text { literatury) } \\
\text { T. Grabowski (oraz wznowienie po } 1945 \text { r.) } \\
\text { J. Kallenbach } \\
\text { L. Kamykowski } \\
\text { Z. Klemensiewicz (filologia polska) } \\
\text { S. Kołaczkowski } \\
\text { J. Krzyżanowski } \\
\text { S. Pigoń } \\
\text { R. Pollak } \\
\text { M. Szyjkowski } \\
\text { S. Tarnowski } \\
\text { J. Tretiak } \\
\text { J. Ujejski } \\
\text { S. Windakiewicz }\end{array}$ \\
\hline Dydaktyka języka polskiego & 1 & Z. Klemensiewicz (rozszerzenie) \\
\hline Fonetyka & 2 & $\begin{array}{l}\text { T. Benni } \\
\text { M. Dłuska }\end{array}$ \\
\hline Historia literatur słowiańskich & 9 & $\begin{array}{l}\text { W. Bobek } \\
\text { W. Kuraszkiewicz (filologia słowiańska) } \\
\text { T. Lehr-Spławiński (filologia słowiańska) } \\
\text { M. Małecki (filologia słowiańska) } \\
\text { T. Milewski (językoznawstwo słowiańskie) } \\
\text { K. Nitsch (filologia słowiańska) } \\
\text { S. Rospond (filologia słowiańska) } \\
\text { W. Taszycki } \\
\text { M. Zdziechowski (filologia słowiańska) }\end{array}$ \\
\hline Filologia romańska & 5 & $\begin{array}{l}\text { M. Brahmer } \\
\text { W. Folkierski (ze szczególnym uwzględnieniem } \\
\quad \text { literatur nowoczesnych) } \\
\text { J. Morawski } \\
\text { S. Stroński } \\
\text { S. Wędkiewicz (ze szczególnym uwzględnieniem } \\
\quad \text { językoznawstwa) }\end{array}$ \\
\hline Filologia angielska & 1 & R. Dyboski (przeniesienie z Wiednia) \\
\hline Filologia indyjska & 3 & $\begin{array}{l}\text { A. Gawroński } \\
\text { E. Słuszkiewicz } \\
\text { L. Mańskowski (sanskryt, przeniesienie } \\
\quad \text { z Wiednia) }\end{array}$ \\
\hline Literatura ruska & 4 & $\begin{array}{l}\text { L. Jankowski (ze szczególnym uwzględnieniem li- } \\
\text { teratur wschodniosłowiańskich) } \\
\text { C. Studziński (język i literatura ruska) } \\
\text { J. Tretiak (historia i literatura ruska, rozszerzenie) } \\
\text { J. Ziłyński (językoznawstwo ruskie) }\end{array}$ \\
\hline
\end{tabular}




\begin{tabular}{|l|l|l|}
\hline Orientalistyka & 1 & T. Kowalski \\
\hline Filologia klasyczna & 11 & A. Krokiewicz \\
& & B. Kruczkiewicz \\
& & K.F. Kumaniecki \\
& & A. Miodoński \\
& & K. Morawski \\
& & G. Przychocki \\
& & J. Sajdak (oraz wznowienie po przejściu na eme- \\
& & J. Schnayder \\
& & T. Sinko \\
& & S. Skimina \\
& L. Sternbach (przeniesienie ze Lwowa) \\
\hline Literatura powszechna nowo- & 1 & M. Mann \\
żytna & & T. Milewski (rozszerzenie) \\
\hline $\begin{array}{l}\text { Językoznawstwo indoeuro- } \\
\text { pejskie }\end{array}$ & 4 & J. Otrębski \\
& & J. Rozwadowski \\
Językoznawstwo afrykańskie & 1 & M. Rudnicki \\
\hline
\end{tabular}

Źródło: AUJ, WF II 121, Teczki habilitacyjne.

Tabela 2. Habilitacje niedokończone (odrzucone, niezatwierdzone)

\begin{tabular}{|l|c|l|}
\hline \multicolumn{1}{|c|}{ Przedmiot (zakres) } & Liczba & \multicolumn{1}{c|}{ Osoba } \\
\hline Filologia niemiecka & 5 & O. Floeck (historia literatury niemieckiej, nieprzy- \\
& & jęte przez Kolegium) \\
& & M. Kawczyński (nie nadesłał dokumentów) \\
& J. Molin (historia języka i literatury niemieckiej) \\
& & A. Pechnik (język i literatura niemiecka; \\
& & Kolegium uznało przedłożone prace za niewy- \\
& & starczające) \\
& & B. Rosenthal \\
\hline
\end{tabular}




\begin{tabular}{|l|c|l|}
\hline Filologia romańska & 4 & $\begin{array}{l}\text { K. Osiecimski (z uwzględnieniem literatury i ję- } \\
\text { zyka włoskiego; Kolegium odrzuciło podanie } \\
\text { z powodu nieposiadania przez petenta doktoratu) } \\
\text { J. Reinhold (podanie składał czterokrotnie) } \\
\text { A. Świtkowski } \\
\text { B. Ziołecki (podanie składał dwukrotnie, Kole- } \\
\text { gium uznało prace za niewystarczające) }\end{array}$ \\
\hline $\begin{array}{l}\text { Historia języka polskiego oraz } \\
\text { porównawczości języka pol- } \\
\text { skiego z innymi językami sło- } \\
\text { wiańskimi (filologia historyczna) }\end{array}$ & 1 & $\begin{array}{l}\text { J. Radwański (podanie składał trzykrotnie, gdyż } \\
\text { nie posiadał doktoratu) }\end{array}$ \\
\hline Filologia klasyczna & 1 & $\begin{array}{l}\text { S. Witkowski (nie przedłożył drukowanej rozpra- } \\
\text { wy) }\end{array}$ \\
\hline
\end{tabular}

Źródło: AUJ, WF II 121 Teczki habilitacyjne.

Bez najmniejszych przeszkód przeszły habilitacje: Henryka Andersa z zakresu filologii niemieckiej (zatwierdzenie przez: Radę - 27 V 1938 r., Senat - 14 VI 1938 r., MWRiOP - 26 VII 1938 r. $)^{16}$, Adama Bełcikowskiego z zakresu historii literatury polskiej (Kolegium - 24 V 1870 r., MWiO - 13 VII 1870 r.) ${ }^{17}$, Mieczysława Brahmera z zakresu filologii romańskiej (Rada - 23 II 1931 r., Senat - 3 III 1931 r., MWRiOP - 12 III 1931 r.) ${ }^{18}$, Marii Dłuskiej z zakresu fonetyki ogólnej (Rada 18 I 1935 r., Senat - 26 II 1935 r., MWRiOP - 11 IX 1935 r.) ${ }^{19}$, Władysława Folkierskiego z zakresu filologii romańskiej ze szczególnym uwzględnieniem literatur nowoczesnych (Kolegium - 16 I 1920 r., MWRiOP - 6 II 1920 r.) ${ }^{20}$, Tadeusza Grabowskiego z zakresu historii literatury polskiej (Kolegium - 11 V 1901, MWiO 7 VIII 1901 r. $)^{21}$, Ludwika Janowskiego z zakresu literatury ruskiej z uwzględnieniem literatur wschodniosłowiańskich (Kolegium - 7 VII 1911 r., MWiO - 2 IX 1911 r.) ${ }^{22}$, Józefa Kallenbacha z zakresu historii literatury polskiej (Kolegium - 18 VII, MWiO - 31 VIII 1887 r. $)^{23}$, Ludwika Kamykowskiego z zakresu historii literatury polskiej (Rada - 18 I 1935 r., Senat - 26 II1935 r., MWRiOP - 6 IX1935 r.) $)^{24}$, Adama Kleczkowskiego z zakresu filologii niemieckiej (Kolegium - 10 X 1919 r., MWRiOP - 6 XI 1919 r. $)^{25}$, Stefana Kołaczkowskiego z zakresu historii literatury polskiej

\footnotetext{
16 AUJ, WF II 121, Teczka habilitacyjna H. Andersa.

17 AUJ, WF II 121, Teczka habilitacyjna A. Bełcikowskiego.

18 AUJ, WF II 121, Teczka habilitacyjna M. Brahmera.

19 AUJ, WF II 121, Teczka habilitacyjna M. Dłuskiej

20 AUJ, WF II 121, Teczka habilitacyjna W. Folkierskiego.

21 AUJ, WF II 121, Teczka habilitacyjna T. Grabowskiego.

22 AUJ, WF II 121, Teczka habilitacyjna L. Janowskiego.

23 AUJ, WF II 121, Teczka habilitacyjna J. Kallenbacha.

24 AUJ, WF II 121, Teczka habilitacyjna L. Kamykowskiego.

25 AUJ, WF II 121, Teczka habilitacyjna A. Kleczkowskiego.
} 
(Rada - 28 VI 1928 r., MWRiOP - 16 VIII 1928 r.) ${ }^{26}$, Adama Krokiewicza z zakresu filologii klasycznej (Rada - 10 II 1922 r., MWRiOP - 10 IV 1922 r.) ${ }^{27}$, Bronisława Kruczkiewicza (Kolegium - 12 XII 1877 r., MWiO - 20 V 1878r.) ${ }^{28}$, Juliana Krzyżanowskiego z zakresu historii literatury polskiej (Rada - 26 VI 1926 r., MWRiOP - 21 VII 1926 r. $)^{29}$, Kazimierza Feliksa Kumanieckiego z zakresu filologii klasycznej (Rada - 1 VII 1930 r., Senat - 14 X 1930 r., MWRiOP - 21 X 1930 r.) ${ }^{30}$, Władysława Kuraszkiewicza z zakresu filologii słowiańskiej (Rada - 22 VI 1934 r., Senat 4 VII 1934 r., MWRiOP - 24 X 1934 r.) $)^{31}$, Tadeusza Lehr-Spławińskiego z zakresu filologii słowiańskiej (Kolegium - 4 III 1918 r., MWiO - 15 VI 1918 r.) ${ }^{32}$, Zygmunta Łempickiego z zakresu filologii niemieckiej (Kolegium - 11 V 1916 r., MWiO - 4 II 1917 r.) ${ }^{33}$, Mieczysława Małeckiego z zakresu filologii słowiańskiej (Rada - $2 \mathrm{~V}$ 1930 r., MWRiOP - 24 V 1930 r. $)^{34}$, Maurycego Manna z zakresu historii literatury powszechnej nowożytnej (Kolegium - 6 V 1911 r., MWiO - 22 VIII 1911 r.) $)^{35}$, Kazimierza Nitscha z zakresu filologii słowiańskiej (MWiO - 4 XII 1905 r.) ${ }^{36}$, Jana Otrębskiego z zakresu językoznawstwa indoeuropejskiego (Rada - 14 VI 1924 r., MWRiOP - 19 VII 1924 r.) ${ }^{37}$, Karola Petelenza z zakresu filologii niemieckiej (język i historia literatury niemieckiej; warto dodać, że cała procedura została przeprowadzona w języku niemieckim; Kolegium - 20 VI 1882 r., MWiO - 27 VII 1882 r. $)^{38}$, Stanisława Pigonia (Rada - 15 IV 1921 r., Senat - 19 IV 1921 r., MWRiOP 14 V 1921 r.) ${ }^{39}$, Romana Pollaka z zakresu historii literatury polskiej (Rada - 17 XI 1922 r., MWRiOP - 17 I 1923 r. $)^{40}$, Gustawa Przychockiego z zakresu filologii klasycznej (Kolegium - 7 V 1913 r.) ${ }^{41}$, Stanisława Rosponda z zakresu filologii słowiań-

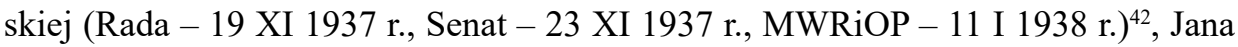
Rozwadowskiego z zakresu językoznawstwa indoeuropejskiego (Kolegium - 21 VI, MWiO - 11 (16) VIII 1902 r. $)^{43}$, Mikołaja Rudnickiego z zakresu językoznawstwa indoeuropejskiego (Kolegium - 4 VII 1912 r., MWiO - 28 IX 1912 r.) ${ }^{44}$, Jana Sajdaka

\footnotetext{
${ }^{26}$ AUJ, WF II 121, Teczka habilitacyjna S. Kołaczkowskiego.

AUJ, WF II 121, Teczka habilitacyjna A. Krokiewicza.

28 AUJ, WF II 121, Teczka habilitacyjna B. Kruczkiewicza.

9 AUJ, WF II 121, Teczka habilitacyjna J. Krzyżanowskiego.

AUJ, WF II 121, Teczka habilitacyjna K. Kumanieckiego.

AUJ, WF II 121, Teczka habilitacyjna W. Kuraszkiewicza.

32 AUJ, WF II 121, Teczka habilitacyjna T. Lehr-Spławińskiego.

3 AUJ, WF II 121, Teczka habilitacyjna Z. Łempickiego.

${ }^{4}$ AUJ, WF II 121, Teczka habilitacyjna M. Małeckiego.

AUJ, WF II 121, Teczka habilitacyjna M. Manna.

${ }^{3}$ AUJ, WF II 121, Teczka habilitacyjna K. Nitscha.

37 AUJ, WF II 121, Teczka habilitacyjna J. Otrębskiego.

38 AUJ, WF II 121, Teczka habilitacyjna K. Petelenza.

39 AUJ, WF II 121, Teczka habilitacyjna S. Pigonia.

${ }^{40}$ AUJ, WF II 121, Teczka habilitacyjna R. Pollaka.

${ }^{41}$ AUJ, WF II 121, Teczka habilitacyjna G. Przychockiego.

42 AUJ, WF II 121, Teczka habilitacyjna S. Rosponda.

43 AUJ, WF II 121, Teczka habilitacyjna J. Rozwadowskiego.

44 AUJ, WF II 121, Teczka habilitacyjna M. Rudnickiego.
} 
z zakresu filologii klasycznej (Kolegium - 13 VII 1912 r., MWiO - 3 IX 1912 r.) ${ }^{45}$, Jerzego Schnaydera z zakresu filologii klasycznej (Rada - 23 VI, Senat - 28 VI, MWRiOP - 17 VIII 1939 r.) ${ }^{46}$, Tadeusza Sinki (MWRiOP - 31 III 1904 r.) ${ }^{47}$, Stanisława Skiminy z zakresu filologii klasycznej (Rada - 13 I 1928 r., MWRiOP 13 II 1928 r.) ${ }^{48}$, Eugeniusza Słuszkiewicza z zakresu filologii indyjskiej (Rada 21 X 1938 r., Senat - 3 XII 1938 r., MWRiOP-21 XII 1938 r.) $)^{49}$, Cyryla Studzińskiego z zakresu języka i literatury ruskiej (Kolegium - 30 X 1896 r., MWiO - 13 I 1897 r.) ${ }^{50}$, Witolda Taszyckiego z zakresu filologii słowiańskiej (językoznawstwa słowiańskiego; Rada - 6 XI 1925 r., MWRiOP - 4 I 1926r.) $)^{51}$, Józefa Ujejskiego z zakresu historii literatury polskiej (Kolegium - 7 V 1917 r., MWiO - 28 VII 1917 r.) ${ }^{52}$, Stanisława Windakiewicza z zakresu historii literatury polskiej (MWiO - $30 \mathrm{IV} 1896 \mathrm{r}$.) $)^{53}$ oraz Mariana Zdziechowskiego (Kolegium - 26 IV 1894 r., Najwyższe postanowienie z 5 VIII 1894 roku MWiO - 15 VIII 1894 r. $)^{54}$.

Pewne pozanaukowe kłopoty z zatwierdzeniem habilitacji z zakresu fonetyki (Kolegium - 18 VI 1914 r.) miał Tytus Benni. Wysłane dokumenty pomiędzy Krakowem a Wiedniem (via Namiestnictwo we Lwowie) zaginęły. Dziekanat Wydziału Filozoficznego kilkakrotnie w 1917 roku oraz w 1918 roku próbował przyspieszyć (urgensował) w MWiO sprawę zatwierdzenia prawa wykładania. Odpowiedni akt wiedeńskie ministerstwo wydało dopiero 21 czerwca 1918 roku, ale chyba dokument nie dotarł do Krakowa na czas, gdyż Senat Akademicki UJ 15 stycznia1919 roku ${ }^{55}$ zatwierdził Benniego jako docenta ${ }^{56}$.

Kilkanaście osób uzyskało w Krakowie prawo wykładania z jednoczesnym nostryfikowaniem dyplomów doktorskich uzyskanych na obcych (poza Austrią) uniwersytetach. Do tego grona należał Andrzej Gawroński, który uzyskał venia legendi z zakresu filologii indyjskiej (Kolegium - 19 III 1912 r., MWiO - 15 V 1912 r.) łącznie z nostryfikacją dyplomu doktorskiego uzyskanego na Uniwersytecie w Lipsku. Przy tej habilitacji warto wspomnieć, że kolegium profesorów wyznaczyło dwóch referentów w osobach Josefa Zubaty'ego z Uniwersytetu Czeskiego w Pradze (na co wyraziło zgodę wiedeńskie Ministerium) i Jana Rozwadowskiego, który „dołączył się” do referatu $^{57}$. Adam Miodoński habilitował się z zakresu filologii klasycznej (Kolegium -

45 AUJ, WF II 121, Teczka habilitacyjna J. Sajdaka.

46 AUJ, WF II 121, Teczka habilitacyjna J. Schnaydera.

47 AUJ, WF II 45, Protokoły posiedzeń Rady Wydziału Filozoficznego.

48 AUJ, WF II 121, Teczka habilitacyjna S. Skiminy.

49 AUJ, WF II 121, Teczka habilitacyjna E. Słuszkiewicza.

50 AUJ, WF II 121, Teczka habilitacyjna C. Studzińskiego.

51 AUJ, WF II 121, Teczka habilitacyjna W. Taszyckiego.

52 AUJ, WF II 121, Teczka habilitacyjna J. Ujejskiego.

53 AUJ, WF II 121, Teczka habilitacyjna S. Windakiewicza.

54 AUJ, WF II 121, Teczka habilitacyjna M. Zdziechowskiego.

55 Takie prawo otrzymał tymczasowo Senat Akademicki UJ do czasu ustabilizowania się sytuacji w kraju w latach 1918-1919. Zob. szerzej: AUJ, S II 525, Władze nadrzędne oświatowe i polityczne, pismo A. Ponikowskiego z 3 XI 1918 r. (drugie pismo).

56 AUJ, WF II 121, Teczka habilitacyjna T. Benniego.

57 AUJ, WF II 121, Teczka habilitacyjna A. Gawrońskiego. 
29 I 1891 r., MWiO - 13 VII 1891 r.). Nostryfikacja jego doktoratu z Uniwersytetu w Erlagen została odłożona w czasie tylko do momentu przedłożenia oryginalnego dyplomu, co nastąpiło przed 1 października 1892 roku$^{58}$. Józef Morawski przy uzyskaniu venia legendi $\mathrm{z}$ zakresu filologii romańskiej ze szczególnym uwzględnieniem literatur średniowiecznych (Kolegium - 18 VI 1920 r., MWRiOP - 25 VII 1920 r.) nostryfikował doktorat z paryskiej Sorbony ${ }^{59}$. Kazimierz Morawski, który habilitował się z zakresu filologii klasycznej (Kolegium - 15 XI 1877 r., MWiO - 17 IV 1878 r.), nostryfikował doktorat filozofii z Uniwersytetu w Berlinie ${ }^{60}$. Stanisław Stroński przy uzyskaniu venia legendi z zakresu filologii romańskiej (Kolegium - 23 III 1909 r., MWiO - 14 VII 1909 r.) nostryfikował w UJ doktorat filozofii uzyskany w Sorbonie ${ }^{61}$.

Jedyną osobą całkowicie zwolnioną z drugiego (kolokwium/dyskusja habilitacyjna) oraz trzeciego (wykład) stadium habilitacji - nie licząc rozszerzenia posiadanego prawa wykładania - był Jan Ziłyński, który 22 maja 1930 roku na podstawie rozprawy Opis fonetyczny języka ukraińskiego (Kraków 1930) wniósł podanie o udzielenie venia legendi $\mathrm{z}$ zakresu językoznawstwa ruskiego (języków ruskich). Rada wyznaczyła na referentów J. Rozwadowskiego, K. Nitscha oraz T. Lehr-Spławińskiego. Referat opracował ten ostatni, a pozostała dwójka się dołączyła. Na jego podstawie Rada 19 czerwca 1931 roku dodatkowo uchwaliła, co następuje:

Ze względu zaś na to, że dr J. Ziłyński nie rozpocznie dopiero pracy naukowej, ale jest już wytrawnym uczonym, mającym za sobą szereg prac, i że od lat pięciu jako zastępca profesora znany jest jako dobry wykładowca, uchwalono jednomyślnie zwolnić go od kolokwium i od wykładu habilitacyjnego i udzielić mu veniam legendi z zakresu językoznawstwa ruskiego (wschodniosłowiańskiego) ${ }^{62}$.

Uchwałę potwierdził Senat Akademicki 23 czerwca 1931 roku, a 24 sierpnia 1931 roku zatwierdziło ją MWRiOP ${ }^{63}$. Tylko od kolokwium został zwolniony Stanisław Wędkiewicz, który habilitował się z zakresu filologii romańskiej ze szczególnym uwzględnieniem językoznawstwa (Kolegium - 13 II 1920 r., MWRiOP - 12 III 1920 r.) ${ }^{64}$. Warto tutaj wspomnieć o Zenonie Klemensiewiczu. Wniósł on podanie o udzielenie venia legendi z zakresu filologii polskiej. Rada po odbyciu kolokwium (dyskusji habilitacyjnej) 1 lipca 1930 roku uchwaliła zwolnienie kandydata z wykładu (Rada - 21 X 1930 r., Senat - 18 XI 1930 r., MWRiOP - 25 XI 1930 r.). Dodatkowo Klemensiewicz rozszerzył posiadane prawo wykładu na dydaktykę języka polskiego, a przy tej procedurze został zwolniony zarówno z kolokwium, jak i wykładu (Rada 27 I 1933 r., MWRiOP - 21 VI 1933 r.) ${ }^{65}$.

\footnotetext{
58 AUJ, WF II 121, Teczka habilitacyjna A. Miodońskiego.

59 AUJ, WF II 121, Teczka habilitacyjna J. Morawskiego.

60 AUJ, WF II 121, Teczka habilitacyjna K. Morawskiego.

${ }^{61}$ AUJ, WF II 121, Teczka habilitacyjna S. Strońskiego.

${ }^{62}$ AUJ, WF II 121, Teczka habilitacyjna J. Ziłyńskiego.

63 Ibidem.

${ }^{64}$ AUJ, WF II 121, Teczka habilitacyjna S. Wędkiewicza.

65 AUJ, WF II 121, Teczka habilitacyjna Z. Klemensiewicza.
} 
Tak jak przy habilitacji Andrzeja Gawrońskiego do referatu obcych (czyli z zagranicy) profesorów poproszono jeszcze dwukrotnie. Pierwszy raz, jeszcze za czasów austriackich, przy habilitacji Tadeusza Kowalskiego z zakresu orientalistyki, a dokładnie: ,[...] z filologii arabskiej, z uwzględnieniem kulturalnego i językowego podłoża semickiego i z kultury i języków islamu (tj. arabskiego, nowoperskiego i osmańsko-tureckiego)", Kolegium Profesorów Wydziału Filozoficznego wyznaczyło na referenta księdza Jana Korzonkiewicza oraz (za zgodą MWiO) zaprosiło jako egzaminatora profesora Rudolfa Geyera z Wiednia (Kolegium - 6 VII 1914 r. MWiO 25 VI 1915 r. $)^{66}$. Drugi raz wydarzyło się to w czasach II Rzeczypospolitej, kiedy podanie wniósł Władysław Bobek pragnący uzyskać venia legendi z zakresu historii literatur słowiańskich. Rada 2 czerwca 1933 roku wyznaczyła komisję w składzie: Nitsch, Pigoń, Wojsłav Molè, Lehr-Spławiński oraz Josef Hanus z Jugosławii. Hanus z Pigoniem byli autorami referatu (Rada - 20 X 1933 r., MWRiOP - 3 I 1934 r.) ${ }^{67}$.

Posiadane prawo wykładu rozszerzyło kilka osób. Henryk Gaertner habilitację z zakresu filologii polskiej ze szczególnym uwzględnieniem stylistyki (Rada - 15 XII 1922 r., MWRiOP - 26 I 1923 r.) rozszerzył do starszej literatury polskiej (Rada - 26 VI 1925 r., MWRiOP - 21 VII 1925r. ${ }^{68}$. Tadeusz Milewski, uzyskawszy uprzednio venia legendi z zakresu językoznawstwa słowiańskiego (Rada - 20 X 1933 r., MWRiOP - 3 I 1934 r.), rozszerzył ją na językoznawstwo indoeuropejskie, ale przy rozszerzeniu venia legendi został zwolniony tylko z trzeciego stadium habilitacji (Rada - 11 VI 1937 r., MWRiOP - 23 VIII 1937 r.) ${ }^{69}$. Ostatnią osobą, która rozszerzyła habilitację, był Józef Tretiak. Posiadane venia legendi z zakresu historii literatury polskiej (Kolegium - 14 VII 1890 r., MWiO - 12 IX 1890 r.) rozszerzył na język i literaturę ruską. Kolegium przy tej drugiej procedurze zwolniło petenta tylko z kolokwium (Kolegium - 5 XII 1892 r., MWiO - 17 II 1893 r.) $)^{70}$.

Dwukrotnie podanie składał (to drugie zostało przyjęte) Stanisław Tarnowski. Przy pierwszym podaniu o udzielenie venia legendi z zakresu historii literatury polskiej, nie mając doktoratu, przedłożył dyplom członkowski Towarzystwa Naukowego Krakowskiego. Kolegium Profesorów w grudniu 1868 roku po referacie Mecherzyńskiego rozpatrzyło prośbę negatywnie. Drugie podanie Tarnowski - nadal nie posiadając doktoratu, a jedynie będąc $\mathrm{w}$ trakcie składania rygorozów - złożył 1 maja 1869 roku i tym razem Mecherzyński, opierając się właśnie na fakcie składania rygorozów ze skutkiem pomyślnym, wniósł o dopuszczenie podania do procedowania. Powoływał się przy tym na zapis reskryptu ministerialnego, że w wyjątkowych przypadkach Kolegium może odstąpić od wymogu posiadania przez kandydata ubiegającego się o prawo wykładania stopnia doktorskiego (Kolegium - 14 V, MWiO - 31 VIII 1869 r. $)^{71}$. Dwukrotnie podanie składał również Marian Szyjkowski. Pierwsze po wyznaczeniu referentów zostało najpewniej wycofane, mimo że Chrzanowski

\footnotetext{
${ }^{66}$ AUJ, WF II 121, Teczka habilitacyjna T. Kowalskiego.

${ }^{67}$ AUJ, WF II 121, Teczka habilitacyjna W. Bobka.

68 AUJ, WF II 121, Teczka habilitacyjna H. Gaertnera.

${ }^{69}$ AUJ, WF II 121, Teczka habilitacyjna T. Milewskiego.

70 AUJ, WF II 121, Teczka habilitacyjna J. Tretiaka.

${ }^{71}$ AUJ, WF II 121, Teczka habilitacyjna S. Tarnowskiego.
} 
napisał referat z pozytywną konkluzją. Drugie podanie, na podstawie innej rozprawy, przyjęto, a sprawa znalazła swój szczęśliwy finał (Kolegium - 6 XII 1913 r., MWiO -28 IV 1914 r. $)^{72}$.

W jednym przypadku kandydat do tytułu docenta był proszony o poprowadzenie wykładu habilitacyjnego dwukrotnie. Mowa o Józefie Birkenmajerze pragnącym się habilitować z zakresu literatury polskiej. Kolokwium zostało jednomyślnie przyjęte, lecz wykład: „Polskie żywotopisarstwo świętych (hagiografia)” po dyskusji z udziałem Chrzanowskiego, Sinki, Semkowicza, Rubczyńskiego, Pigonia, Dyboskiego i Folkierskiego, na wniosek Pigonia, uznano za niewystarczający i wyznaczono inny temat: „Epos polski bohaterski na przełomie XVIII i XIX w.”. Ten powtórzony wykład, przy trzech głosach sprzeciwu, został przyjęty i cała procedura zakończyła się pozytywnie (Rada - 29 X 1937 r., Senat - 23 XI 1937 r., MWRiOP - 11 I 1938 r.) ${ }^{73}$.

Habilitacje uzyskane na innych uniwersytetach reprezentowanych w austriackiej Radzie Państwa lub po 1918 roku na uczelniach II Rzeczypospolitej przenieśli na UJ: Roman Dyboski - uzyskaną habilitację z zakresu filologii angielskiej na Uniwersytecie w Wiedniu (Kolegium - 21 VII 1908 r., MWiO 27 VIII 1908 r. zatwierdziło habilitację wiedeńską z jednoczesnym przeniesieniem do Krakowa ${ }^{74}$, Leon Mańkowski - docent prywatny języka sanskryckiego i literatury indyjskiej na Uniwersytecie w Wiedniu (Kolegium - 17 XII 1892 r., MWiO - 7 I 1893 r.) - przeniósł habilitację na UJ (Kolegium, kurendą 30 I 1893 r., MWiO - 20 IV 1893 r.) ${ }^{75}$, Roman Stopa - docent językoznawstwa afrykańskiego Uniwersytetu Jana Kazimierza - przeniósł venia legendi do Krakowa (Rada - 21 X 1938 r., co MWRiOP „, [...] przyjęło do wiadomości” 30 XI 1938 r.) $)^{76}$, Leon Sternbach - docent prywatny zakresu filologii klasycznej Uniwersytetu we Lwowie - przeniósł habilitację na UJ, na co MWiO przystało 28 listopada $1891 \mathrm{roku}^{77}$.

$* * *$

Habilitacji nie uzyskali: Oswald Floeck z zakresu historii literatury niemieckiej, gdyż Kolegium Profesorów nie przyjęło kolokwium ${ }^{78}$; Maksymilian Kawczyński z zakresu filologii niemieckiej, ponieważ nie nadesłał on wymaganych dokumentów ${ }^{79}$; Jan Molin z zakresu historii języka i literatury niemieckiej, gdyż Kolegium

72 AUJ, WF II 121, Teczka habilitacyjna M. Szyjkowskiego.

73 AUJ, WF II 121, Teczka habilitacyjna J. Birkenmajera.

74 AUJ, WF II 121, Teczka habilitacyjna R. Dyboskiego.

75 AUJ, WF II 121, Teczka habilitacyjna L. Mańkowskiego.

76 AUJ, WF II 121, Teczka habilitacyjna R. Stopy.

77 AUJ, WF II 121, Teczka habilitacyjna L. Sternbacha.

78 AUJ, WF II 121, Teczka habilitacyjna O. Floecka.

79 Habilitację przeprowadził na Uniwersytecie we Lwowie (filologia niemiecka [1882 r.], którą rozszerzył o filologię romańską [1888 r.]). Następnie od 1892 r. był profesorem UJ. Zob. szerzej: AUJ, S II 619, Teczka personalna M. Kawczyńskiego; WF II 121, Teczka habilitacyjna M. Kawczyńskiego; Державнийархів Львівськоїобласті, fond 26, opis 5, sprawa 778, Teczka personalna M. Kawczyńskiego; Z. Czerny, Kawczyński Maksymilian [w:] Polski Stownik Biograficzny (dalej: PSB), t. 12, 1966 1967, s. 241 i nn. 
Profesorów - po referacie Tomasza Bratranka, do którego przyłączył się Iskrzycki uznało rozprawę za niewystarczającą do przeprowadzenia habilitacji ${ }^{80}$. Podobnie było z podaniem Aleksandra Pechnika pragnącego się habilitować z filologii niemieckiej (języka i literatury niemieckiej). Kolegium po referatach Tarnowskiego i Bratranka uznało przedłożone rozprawy za niewystarczające ${ }^{81}$. Konstanty Osiecimski nie został dopuszczony do habilitacji z zakresu filologii romańskiej (literatury i języka włoskiego) z powodu niespełniana warunków prawem przepisanych - nie miał doktoratu. Otrzymał jedynie zgodę wykładania języka włoskiego w salach uniwersyteckich $^{82}$. Nieznane są losy podania Bronisławy Rosenthal pragnącej uzyskać venia legendi $\mathrm{z}$ zakresu filologii niemieckiej ${ }^{83}$. Kolegium profesorów 9 stycznia 1862 roku odrzuciło prośbę Augusta Świtkowskiego o udzielenie venia legendi z zakresu filologii romańskiej ${ }^{84}$. Stanisław Witkowski, wnosząc podanie o udzielenie venia legendi z zakresu filologii klasycznej, przedstawił rozprawę jeszcze nieopublikowaną. Wyznaczeni referenci - Morawski i Sternbach - uznali przedłożoną pracę za wystarczającą, ale dziekan 21 października1894 roku odpisał petentowi, że procedura ruszy dopiero wtedy, gdy przedłoży pracę już wydrukowaną̧ ${ }^{85}$. Dwukrotnie podanie składał Bolesław Ziołecki. Pierwsze (z 1883 r.) dotyczyło venia legendi z zakresu języka i literatury angielskiej, a drugie (z 1886 r., uzupełnione w 1887 r.) - filologii romańskiej. W obu przypadkach Kolegium profesorów odrzuciło prośbę, a za argument w tym ostatnim przypadku podano, że przedłożona rozprawa „nie jest żadną nową pracą, żądaną przez Wydział" $"$.

Wspomnę jeszcze o dwóch kandydatach, którzy wytrwale - kilkakrotnie - składali podanie o venia legendi. Pierwszy zostanie przywołany z powodu dość długotrwałych starań. Losy drugiego są istotne z powodu pewnego listu.

Jan Radwański 30 września 1858 roku i w latach następnych domagał się dopuszczenia do wykładów jako niedoszły profesor, gdyż - jak twierdził - jego podpisana nominacja została w ostatniej chwili odwołana. Po odpowiedziach Kolegium Profesorów, które nie były po myśli petenta, 2 oraz 7 grudnia 1861 roku Radwański powołując się na apel Dietla - wniósł podanie o udzielenie venia legendi z zakresu historii języka polskiego oraz porównawczości języka polskiego z innymi językami słowiańskimi (filologia historyczna). Rozprawę Nieco o mitologii polskiej i stowiańskiej w ogóle (Kraków 1862) przedłożył 30 maja 1862 roku. Na podstawie uchwały Kolegium dziekan odpisał 14 lipca 1862 roku, że żadnych praw do zadośćuczynienia Radwański nie ma, a do habilitacji nie może być dopuszczony, bo nie ma doktoratu. 15 października 1870 roku wniósł kolejne podanie i prosił o uznanie studiów na Uniwersytecie w Jenie, a jeśliby wydział na to nie przystał, to petent prosił „tytułem wieku" o zwolnienie z obowiązku posiadania doktoratu. 25 listopada $1870 \mathrm{roku}$

\footnotetext{
${ }^{80}$ AUJ, WF II 121, Teczka habilitacyjna J. Molina.

$\$ 1$ AUJ, WF II 121, Teczka habilitacyjna A. Pechnika.

82 AUJ, WF II 121, Teczka habilitacyjna K. Osiecimskiego.

3 AUJ, WF II 121, Teczka habilitacyjna B. Rosenthal.

4 AUJ, WF II 121, Teczka habilitacyjna A. Świtkowskiego.

5 AUJ, WF II 121, Teczka habilitacyjna S. Witkowskiego.

${ }^{86}$ AUJ, WF II 121, Teczka habilitacyjna B. Ziołeckiego.
} 
wydział ponownie odrzucił prośbę (mimo że referent Henryk Suchecki wniósł o dopuszczenie do habilitacji), gdyż kandydat nadal nie posiadał doktoratu, a Kolegium nie zamierzało skorzystać z przysługującego mu prawa do zwolnienia petenta $\mathrm{z}$ tego obowiązku. Dziekan Karliński odpisał 28 listopada 1870 roku, że Kolegium uchwaliło albo przedłożenie do nostryfikacji doktoratu, albo uzyskanie takowego na którymś $\mathrm{z}$ uniwersytetów austriackich jako warunek sine qua non rozpatrzenia podania o habilitację. Kolejne podanie przedłożył Radwański 24 marca 1872 roku i tym razem powołał się na swoją korespondencję z wiedeńskim ministerstwem. Ostateczna decyzja jednak zawsze należała do Kolegium profesorów i MWiO nie mogło narzucić decyzją administracyjną swojej woli w kwestii dopuszczenia jakiegokolwiek kandydata do procedury uzyskania venia legendi. 24 marca 1872 roku Kolegium - tym razem po uwzględnieniu opinii Tarnowskiego - ponownie nie przyjęło podania, nie uchwaliło zwolnienia kandydata z posiadania dyplomu doktorskiego i odrzuciło podanie o venia legendi ${ }^{87}$. Dodatkowo warto zwrócić uwagę, że ostatnim referentem $\mathrm{w}$ tej sprawie była osoba, która swego czasu również wniosła podanie o udzielenie prawa wykładania, nie posiadając doktoratu. Przy procedowaniu nad podaniem Tarnowskiego nie da się jednak nie zauważyć życzliwości względem petenta.

Drugą osobą jest Joachim (Henryk Joachim) Reinhold, który trzykrotnie (14 IV 1909 r., 20 V 1911 r. oraz 30 XII 1932 r.) składał podanie o udzielenie venia legendi z zakresu filologii romańskiej. Pierwsze dwa podania zostały odrzucone po referatach (przeważyło stanowisko Stanisława Strońskiego) uznających przedłożone prace za niewystarczające jako podstawa habilitacji. Trzecie podanie Reinhold złożył jako emerytowany nauczyciel, były profesor Wolnej Wszechnicy Polskiej w Warszawie i członek Komisji Filologii Polskiej PAU, pragnąc uzyskać venia legendi z zakresu „filologii francusko-włoskiej ze szczególnym uwzględnieniem filologii romańskiej”. Ponad 650-letnie dzieje UJ doprowadziły do wykrystalizowania się pewnych tradycji i (jak zapisał Julian Dybiec, co sam również przyjąłem w swojej monografii o Wydziale Prawa) uniwersytet krakowski wszedł w okres II Rzeczypospolitej na podstawie austriackich przepisów oraz zgodnie z wypracowaną ,,wielowiekową tradycją?" Niemniej w nauce szuka się dowodów i potwierdzeń tez. Nie wystarczają domysły i zastany fakt. Dowodem potwierdzającym istnienie swoistej procedury jest list. 4 marca 1933 roku dziekan Zdzisław Jachimecki napisał go do Reinholda, który przedstawię in extenso:

Poczuwam się do obowiązku podania do wiadomości Pana Profesora, że w sprawie habilitacji Pańskiej zwracał się do mnie Prof. Folkierski z zastrzeżeniem formalnym wynikającem z przyjętych u nas zwyczajów, według których kandydaci wnoszący podanie o habilitację porozumiewają się z przedstawicielami danej specjalności naukowej. Ponieważ w czasie, kiedy Pan Profesor był w Krakowie, celem zgłoszenia Swojego podania o habilitację, nieobecność Profesora Folkierskiego uniemożliwiła Panu porozumienie się z Prof. Folkierskim, więc dzisiaj pozwalam sobie zwrócić uwagę Pańską na konieczność powiadomienia o zamiarze Pańskim Profesora Folkierskiego i o uzyskaniu prywatnie jego zgody na urzędowe załatwienie sprawy ${ }^{89}$.

87 AUJ, WF II 121, Teczka habilitacyjna J. Radwańskiego.

${ }^{88}$ J. Dybiec, Uniwersytet Jagielloński 1918-1939, Kraków 2000, s. 61.

89 AUJ, WF II 121, Teczka habilitacyjna J. Reinholda. 
To, że Rada 24 kwietnia1936 roku dopuściła kandydata do dalszych stadiów habilitacji ${ }^{90}$, świadczy o tym, że ubiegający się o venia legendi kandydat uczynił zadość prośbie dziekana. Niemniej dla liczącego już wówczas 53 lata człowieka, uznanego w świecie filologów romańskich, było to za wiele. Nie kontynuował zabiegów o habilitację i usunął się w cień życia publicznego ${ }^{91}$.

\section{$* * *$}

Przedstawiona wyżej grupa uczonych jest zbyt nieliczna, by na jej przykładzie budować jakieś wielkie i niepodważalne hipotezy czy opisywać całą tę zbiorowość i ją charakteryzować. Jeżeli chodzi o działalność naukową wymienionych tutaj docentów i przyszłych profesorów, to literatura przedmiotu jest ogromna ${ }^{92}$. Niemniej można się pokusić o pewne wnioski i uogólnienia.

1. W Krakowie powstały szkoły filologiczne. Z pewnością dotyczyło to filologii polskiej (historii języka i literatury), filologii słowiańskiej, filologii klasycznej, filologii romańskiej oraz różnych filologii „pozaeuropejskich”, jak orientalna, indyjska czy językoznawstwo afrykańskie.

2. W związku z powyższym - łatwiej niż na innych wydziałach UJ czy kierunkach studiów - da się wychwycić zależność mistrz-uczeń. Ta „genealogia naukowa" jest bardzo prosta do odtworzenia.

3. Większość wyhabilitowanych docentów po uzyskania venia legendi pozostała „W nauce" i otrzymała katedry uniwersyteckie zarówno na UJ, jak i na innych uczelniach.

4. Docenci krakowscy, którzy nie mogli liczyć na katedrę na UJ (nie z powodu nieodpowiednich kwalifikacji, a ze względów budżetowych) otrzymali katedry profesorskie na pozostałych uniwersytetach II Rzeczypospolitej (nie licząc Lwowa) - w Wilnie, Warszawie, Poznaniu - i tam rozwijali się nad wyraz dobrze.

5. Docenci filologii byli, w związku z powyższym, bardziej „mobilni” - przenosili się dość łatwo na inne uczelnie, co może wynikać też z faktu, że całkiem sporo (jak na warunki krakowskie) uzyskało doktoraty poza UJ (na UJ 67\%, poza $33 \%$ ). Na podstawie własnych wyliczeń podaję, że 40 przyszłych docentów doktorat filozofii uzyskało na UJ, pozostali zaś w Wiedniu (6), Lwowie (5), Paryżu (2) oraz w Warszawie, Lipsku, Erlangen, Wrocławiu, Fryburgu, Berlinie i Poznaniu.

a) Prawo wykładania przenieśli: do Wilna na USB - H. Anders oraz J. Otrębski; do Lwowa - M. Dłuska, która po 1945 roku powróciła na UJ, oraz S. Rospond; na Uniwersytet w Poznaniu - J. Sajdak.

90 Ibidem.

91 S. Widłak, Reinhold Joachim Henryk [w:] PSB, t. 31, 1988, s. 24 i nn.

92 Odniosę się tylko do podstawowych pozycji: J. Dybiec, op. cit., passim; U. Perkowska, op. cit., passim; M. Stinia, Uniwersytet Jagielloński w latach 1871-1914. Modernizacja procesu nauczania, Kraków 2014; Wydziat Filologiczny Uniwersytetu Jagiellońskiego. Historia katedr, red. W. Tas zy cki, A. Zaręba, Kraków 1964; Złota Księga Wydziatu Filologicznego, red. J. Michalik, W. Walecki, Kraków 2000. 
b) Profesorami na UJ zostali: R. Dyboski, W. Folkierski, J. Kallenbach (również na Uniwersytecie we Lwowie i w Warszawie oraz na USB), M. Kleczkowski (również na Uniwersytecie w Poznaniu), Z. Klemensiewicz, S. Kołaczkowski, T. Kowalski, T. Lehr-Spławiński (również na Uniwersytecie w Poznaniu, na UJK), M. Małecki, L. Mańkowski, T. Milewski, A. Miodoński, K. Morawski, K. Nitsch (również na Uniwersytecie we Lwowie), S. Pigoń (również na Uniwersytecie w Poznaniu, na USB), J. Rozwadowski, T. Sinko (do 1913 r. na Uniwersytecie we Lwowie), S. Skimina (po 1945 r. krótko na UMK), L. Sternbach, R. Stopa (profesor po 1945 r.), S. Stroński (od 1927 r. - na Katolickim Uniwersytecie Lubelskim), S. Tarnowski, J. Tretiak, S. Windakiewicz, J. Ziłyński (po 1945 r. - na Uniwersytecie w Pradze).

c) Jako docenci wykładali na UJ: A. Bełcikowski, W. Bobek, T. Grabowski, L. Kamykowski (również na KUL), W. Kuraszkiewicz (również na KUL), K. Petelenz, S. Rospond (po 1945 r. na Uniwersytecie we Wrocławiu), J. Schnayder (po 1945 r. na Uniwersytecie w Łodzi), M. Zdziechowski (nie miał katedry, był profesorem tytularnym).

d) Profesorami na innych uniwersytetach zostali:

- na Uniwersytecie w Wisconsin: J. Birkenmajer (miał objąć katedrę na KUL, ale przeszkodził mu wybuch wojny);

- na Uniwersytecie w Warszawie: T. Benni, M. Brahmer, A. Gawroński, A. Krokiewicz (również na KUL), J. Krzyżanowski (również na KUL), K.F. Kumaniecki, Z. Łempicki, M. Mann, G. Przychocki (od 1935 r. na UJ), J. Ujejski, M. Zdziechowski (od 1920 r. na USB);

- na UJK: H. Gaertner, B. Kruczkiewicz (jeszcze na Uniwersytecie we Lwowie), J. Sajdak (jeszcze na Uniwersytecie we Lwowie, od 1946 r. na Uniwersytecie w Poznaniu);

- na KUL: W. Kuraszkiewicz;

- na USB: L. Janowski, J. Otrębski (po 1945 r. w Poznaniu), R. Pollak, W. Taszycki (przed 1945 r. we Lwowie, po 1945 r. ponownie na UJ), M. Zdziechowski;

- na Uniwersytecie w Poznaniu: J. Morawski, M. Rudnicki, S. Wędkiewicz (od 1934 r. na Uniwersytecie w Warszawie, od 1949 r. - na UJ);

- na UMK i na Uniwersytecie w Warszawie: E. Słuszkiewicz (jako docent do 1945 r. we Lwowie);

- na Uniwersytecie we Lwowie, na Uniwersytecie Iwana Franki we Lwowie: C. Studziński;

- na Uniwersytecie w Pradze: M. Szyjkowski ${ }^{93}$.

Krakowscy uczeni byli członkami wielu krajowych i zagranicznych towarzystw naukowych, na przykład Akademii Umiejętności (Polskiej Akademii Umiejętności, przy czym K. Morawski, K. Nitsch, J. Rozwadowski i S. Tarnowski byli prezesami, a T. Kowalski i S. Tarnowski sekretarzami generalnymi), Polskiej Akademii Nauk itd., a także doktorami honoris causa polskich i światowych uczelni - między innymi

93 U. Perkowska, op. cit., passim. 
M. Brahmer (Neapol), M. Dłuska (Chicago), J. Kallenbach (USB), J. Krzyżanowski (UJ, Uniwersytet we Wrocławiu), T. Lehr-Spławiński (Sofia, Praga), K. Nitsch (Paryż, Sofia), J. Rozwadowski (Warszawa, Poznań, UJK), M. Rudnicki (Poznań), L. Sternbach (UJ), Taszycki (Katowice). Tajne nauczanie na UJ podczas II wojny światowej (1942-1945) organizował M. Małecki ${ }^{94}$.

Warto też wspomnieć o pozanaukowej działalności wyhabilitowanych docentówpóźniej już profesorów nie tylko UJ. S. Tarnowski przewodził krakowskim Stańczykom. Działaczami Stronnictwa Narodowego byli W. Folkierski (po 1945 r. minister kilku resortów w Rządzie RP na Uchodźstwie) oraz S. Stroński (dziennikarz, wybitny publicysta, poseł na sejm 1922-1935, minister kilku resortów w Rządzie RP na Uchodźstwie $)^{95}$. W działalność ukraińskiego ruchu politycznego zaangażowali się C. Studziński (poseł do austriackiej Rady Państwa, w latach 1918-1919 internowany przez władze polskie, członek Delegacji Ukraińskiej na Konferencję Pokojową w Paryżu w 1919 r., a po 1939 r. przewodniczący Zgromadzenia Ludowego Zachodniej Ukrainy (26-28 X 1939), od 23 III1940 r. deputowany do Rady Najwyższej ZSRR, od 15 XII 1940 r. radny m. Lwowa) oraz J. Ziłyński (m.in. współpracownik Ukraińskiego Komitetu Centralnego w Krakowie w latach 1939-1940 i dyrektor Ukraińskiego Wydawnictwa w Krakowie w latach 1941-1944) ${ }^{96}$. Józef Ujejski był w 1936 roku wiceministrem wyznań religijnych i oświecenia publicznego. Na koniec trzeba wspomnieć o dwóch kandydaturach na Urząd Prezydenta Rzeczypospolitej. Pierwsza - K. Morawskiego (jako prezesa PAU) - została oficjalnie wysunięta przez Stronnictwo Narodowe, ale przegrał on w głosowaniu ze Stanisławem Wojciechowskim. Drugi, mniej oficjalny kandydat - M. Zdziechowski - jako profesor USB został wysunięty po dymisji S. Wojciechowskiego w 1926 roku. Ostatecznie wybór padł na Ignacego Mościckiego ${ }^{97}$.

Podczas II wojny światowej zmarli lub zostali zamordowani: W. Bobek (KL Auschwitz), L. Kamykowski (zmarł w Krakowie), S. Kołaczkowski (zmarł w Krakowie po zwolnieniu z KL Sachsenhausen), Jan Morawski (zginął w Warszawie 25 IX 1939 r.), L. Sternbach (KL Sachsenhausen) ${ }^{98}$.

Mimo że obecny Wydział Filologiczny UJ jest stosunkowo młodym fakultetem, gdyż powstał w 1951 roku po wyodrębnieniu z Wydziału Humanistycznego, a ten powstał dopiero w 1945 roku, wchodząc wcześniej w skład ogromnego fakultetu filozoficznego, to jednak tradycja nauki i nauczania filologii we Wszechnicy Krakowskiej sięga początków istnienia uczelni. Ten fundament i tradycja - jak zapisał Janusz S. Gruchała - stanowią podstawę badań literackich również współcześnie.

94 Ibidem.

95 AUJ, S II 619, Teczka personalna W. Folkierskiego; S II 619, Teczka personalna S. Strońskiego; W. Rojek, Stroński Stanisław [w:] PSB, t. 44, 2006-2007, s. 381 i nn.

96 AUJ, S II 619, Teczka personalna J. Ziłyńskiego. Zob. szerzej: Збірник пам>яті Івана Зілинського (1879-1952), ред. Ю.Шевельов, Нью-Йорк-Париж-Сідней-Торонто-Львів 1994.

97 AUJ, S II 619, Teczki personalne K. Morawskiego i M. Zdziechowskiego; Lietuvos centrinis valstybės archyvas, f. 175, Teczka personalna M. Zdziechowskiego; S. Pieczara, Morawski Kazimierz [w:] PSB, t. 21, 1976, s. 725 i nn.

98 U. Perkowska, op. cit., passim. 
Przedstawione wyżej sylwetki uczonych i ich drogi od habilitacji do samodzielnego prowadzenia badań są tylko drobnym wycinkiem tej tradycji. Nie przedstawiłem przecież sylwetek tych profesorów, którzy stanowili o świetności krakowskiej filologii, mając tylko doktorat (Jan Łoś, Helena Willman-Grabowska) lub kandydaturę nauk historyczno-filologicznych (Ignacy Chrzanowski). Niemniej ten wycinek potwierdza wysoką pozycję krakowskiej filologii w drugiej połowie XIX i w pierwszej połowie XX wieku. Życzyć sobie należy tylko - idąc za przykładem Fryderyka Zolla juniora, który twierdził, że każdy uczony powinien wychować ucznia lepszego od samego siebie - że ten fundament i ta tradycja będą nadal solidną podstawą do prowadzenia tego typu badań w Krakowie.

\section{BIBLIOGRAFIA}

\section{Źródła prawa}

\section{Ustawy}

Ustawa z 13 VII 1920 r. o szkołach akademickich, DzURP 1920, nr 72, poz. 494.

Ustawa z 15 III 1933 r. o szkołach akademickich, DzURP 1933, nr 29, poz. 247.

\section{Rozporządzenia}

Rozporządzenie Ministra WRiOP z 21 IV 1936 r. o sposobie postępowania habilitacyjnego w państwowych szkołach akademickich, DzURP 1936, nr 38, poz. 290.

Rozporządzenie Ministra WRiOP z 26 VII 1939 r. o sposobie postępowania habilitacyjnego w państwowych szkołach akademickich, DzURP 1939, nr 69, poz. 468.

Rozporządzenie Ministra Oświaty z 25 VI 1945 r. w sprawie postępowania habilitacyjnego w państwowych szkołach akademickich, DzURP 1945, nr 24, poz. 139.

\section{Źródła archiwalne}

Archiwum Uniwersytetu Jagiellońskiego w Krakowie

Akta Senatu Akademickiego

S II 525, Władze nadrzędne oświatowe i polityczne.

S II 583, Docenci prywatni.

S II 619, Teczka personalna: W. Folierskiego, M. Kawczyńskiego, K. Morawskiego,

S. Strońskiego, M. Zdziechowskiego, J. Ziłyńskiego, F. Zolla sen.

Akta Wydziału Filozoficznego

WF II 45, Protokoły posiedzeń Rady Wydziału Filozoficznego.

WF II 121, Teczka habilitacyjna: H. Andersa, A. Bełcikowskiego, T. Benniego, J. Birkenmajera, W. Bobka, M. Brahmera, M. Dłuskiej, R. Dyboskiego, O. Floecka, W. 
Folkierskiego, H. Gaertnera, A. Gawrońskiego, T. Grabowskiego, L. Janowskiego, J. Kallenbacha, L. Kamykowskiego, M. Kawczyńskiego, A. Kleczkowskiego, Z. Klemensiewicza, S. Kołaczkowskiego, T. Kowalskiego, A. Krokiewicza, B. Kruczkiewicza, J. Krzyżanowskiego, K. Kumanieckiego, W. Kuraszkiewicza, T. Lehr-Spławińskiego, Z. Łempickiego, M. Małeckiego, M. Manna, L. Mańkowskiego, T. Milewskiego, A. Miodońskiego, J. Molina, J. Morawskiego, K. Morawskiego, K. Nitscha, J. Otrębskiego, K. Osiecimskiego, A. Pechnika, K. Petelenza, S. Pigonia, R. Pollaka, B. Rosenthal, G. Przychockiego, J. Radwańskiego, S. Rosponda, J. Rozwadowskiego, M. Rudnickiego, J. Sajdaka, J. Schnaydera, S. Skiminy, E. Słuszkiewicza, L. Sternbacha, R. Stopy, S. Strońskiego, C. Studzińskiego, M. Szyjkowskiego, A. Świtkowskiego, S. Tarnowskiego, W. Taszyckiego, J. Tretiaka, J. Ujejskiego, S. Wędkiewicza, S. Windakiewicza, S. Witkowskiego, M. Zdziechowskiego, J. Ziłyńskiego, B. Ziołeckiego.

Akta Wydziału Prawa

WP II 137, Habilitacje i docentury.

WP II 138, Teczka habilitacyjna F. Zolla sen.

Державнийархів Львівськоїобластім. Львів

Akta Uniwersytetu we Lwowie

f. 26, opis 5, sprawa 778, Teczka personalna M. Kawczyńskiego.

Lietuvos Centrinis Valstybès Archyvas w Wilnie (LCVA)

Akta Uniwersytetu Stefana Batorego w Wilnie

f. 175, Teczka personalna M. Zdziechowskiego.

\section{Źródła drukowane}

Die österreichischen Universitätsgesetze. Sammlung der für die österreichischen Universitäten gültigen Gesetze, Verordnungen, Erlässe, Studien- und Prüfungsordnungen, Hrsg. L. Beck von Mannagetta, C. von Kelle, Wien 1906.

Statut Uniwersytetu Jagiellońskiego, Kraków 1925.

Zbiór przepisów o szkolnictwie akademickim. Ustawy, rozporządzenia, okólniki, zebr. A. Ostrowski, Lwów-Warszawa 1938.

\section{Prasa}

„Czas”, nr 251 z 31 X 1861 r. 


\section{Literatura}

Czerny Z., Kawczyński Maksymilian [w:] Polski Słownik Biograficzny, t. 12, 1966-1967.

Dybiec J., Uniwersytet Jagielloński 1918-1939, Kraków 2000.

Estreicher S., Znaczenie Krakowa dla życia narodowego polskiego w ciagu XIX wieku, Kraków 1931.

Horn E., Zur Gesichte der Privatdozenten [w:] Mitteilungen der Gesellschaft für deutsche Erziehungs- und Schulgeschichte, Vol. 11, Berlin 1901.

Jastrzębski J., Habilitacja w państwowym szkolnictwie akademickim II Rzeczypospolitej, „Analecta. Studia i Materiały z Dziejów Nauki” R. XIX, 2010, z. 1-2.

Michalewska K., Habilitacje w Uniwersytecie Jagiellońskim 1848-1918, „Zeszyty Naukowe Uniwersytetu Jagiellońskiego” 1963, nr 71, „Prace Historyczne”, z. 12.

Patkaniowski M., Dzieje Wydziału Prawa Uniwersytetu Jagiellońskiego od reformy kolłatajowskiej do końca XIX stulecia, Kraków 1964.

Perkowska U., Corpus Academicorum Facultatis Philosophiae Universitatis Iagellonicae 1850-1945, Kraków 2007.

Pieczara S., Morawski Kazimierz [w:] Polski Stownik Biograficzny, t. 21, 1976.

Przeniosło M., Stopnie, tytuły i stanowiska naukowe w II Rzeczypospolitej, „Res Historica” 2012.

Rojek W., Stroński Stanisław [w:] Polski Stownik Biograficzny, t. 44, 2006-2007.

Stinia M., Uniwersytet Jagielloński w latach 1871-1914. Modernizacja procesu nauczania, Kraków 2014.

Widłak S., Reinhold Joachim Henryk [w:] Polski Stownik Biograficzny, t. 31, 1988.

Wojtczak K., O stopniach naukowych $i$ venia mlegendi w II Rzeczypospolitej (część I), „Studia Prawa Publicznego" 2014, nr 3.

Wojtczak K., O stopniach naukowych i venia mlegendi w II Rzeczypospolitej (część II), „Studia Prawa Publicznego” 2014, nr 4 (8).

Wydział Filologiczny Uniwersytetu Jagiellońskiego. Historia katedr, red. W. Taszycki, A. Zaręba, Kraków 1964.

Złota Księga Wydziału Filologicznego, red. J. Michalik, W. Walecki, Kraków 2000.

Żukowski P.M., Profesorowie Wydziału Prawa Uniwersytetu Jagiellońskiego, t. 2: 1780 2012, red. D. Malec, Kraków 2014.

Збірник пам>яті Івана Зілинського (1879-1952), ред. Ю. Шевельов, Нью-ЙоркПариж-Сідней-Торонто-Львів 1994. 